\title{
The Wilfredomys pictipes (Rodentia: Sigmodontinae) karyotype with comments on the karyosystematics of Brazilian Thomasomyini
}

\author{
Cibele R. BONVICINO and Ivone OTAZU
}

\begin{abstract}
Bonvicino C. R. and Otazu I. 1999. The Wilfredomys pictipes (Rodentia: Sigmodontinae) karyotype with comments on the karyosystematics of Brazilian Thomasomyini. Acta Theriologica 44: 329-332.
\end{abstract}

Karyotypic analysis of two specimens of Wilfredomys pictipes (Osgood, 1933), collected in the Atlantic forest of São Paulo State, Brazil, showed 2n $=36 / \mathrm{FN}=34$. Comparative karyologic analysis indicated that W. pictipes was very different from species belonging to the tribe Oryzomyini and to the genus Delomys but similar to Rhipidomys species. These findings indicated that the tribe Thomasomyini is not a karyotypically homogeneous taxon. The low diploid number of W. pictipes is likely to be a derived trait among sigmodontine rodents.

Genetics Section, Instituto Nacional de Câncer, Praça da Cruz Vermelha, 23, 20230-130 Rio de Janeiro, RJ, Brazil, e-mail: cibelerb@inca.org.br

Key words: Wilfredomys, karyotype

\section{Introduction}

The genus Wilfredomys comprises two known species, W. oenax (Thomas, 1928) and W. pictipes (Osgood, 1933); the former occurring from SE Brazil to central Uruguay, and the latter in SE Brazil and NE Argentina (Musser and Carleton 1993). Both species were originally described as belonging to the genus Thomasomys (Thomas, 1928; Osgood, 1933); the genus Wilfredomys, to which pictipes and oenax are presently assigned, was later proposed by Ávila-Pires (1960). However, Pine (1980) did not agree with this generic denomination and suggested that "Thomasomys pictipes seems to stand in an annectant position to T. oenax and certain of the Andean forms of the genus". Hershkovitz (1962), following Thomas (1906), grouped the genus Rhipidomys and Thomasomys (including Delomys and Wifredomys) in the tribe Thomasomyini, whereas Reig (1984) grouped Delomys, Wilfredomys and Rhipidomys in the tribe Oryzomyini. Voss (1993), however, proposed that the genus Delomys "is one of many pentalophodont genera that cannot be assigned to any demonstrably monophyletic taxon less inclusive than the Neotropical muroid ingroup identified earlier for the purpose of character analysis" and suggested that this genus, as well as others like Rhipidomys and Wilfredomys, should be considered as a "plesion" in formal classification. 
Despite extensive karyological studies carried out in sigmodontine rodents, the karyotypes of Wilfredomys species are unknown, probably because these species show a restricted distribution and a naturally lower density. Considering the controversial status of Wilfredomys within the Sigmodontinae, karyological data might be useful for elucidating its relationship with other sigmodontine genera. In this paper, we describe the karyotype of W. pictipes and compare it with related forms.

\section{Material and methods}

We analyzed two specimens collected in Intervales farm, São Paulo State (EM 1180 and INT 4). Skins and skulls will be deposited in the mammals collections of Museu Nacional (Rio de Janeiro). Chromosome preparations were obtained from bone marrow cultures in RPMI 1640, 20\% fetal calf serum, ethidium bromide $(5 \mu \mathrm{g} / \mathrm{ml})$ and colchicine $10^{-6} \mathrm{M}$ for two hours. G- and C-banding were done as described by Seabright (1971) and Sumner (1972) respectively.

\section{Results}

Karyological analysis showed $2 \mathrm{n}=36 / \mathrm{FN}=34$. The autosome complement is composed by 17 pair of acrocentric chromosomes varying in size from large to small. The $\mathrm{X}$ chromosome is a medium sized acrocentric and the $\mathrm{Y}$ is a small acrocentric. The G-band karyotype of W. pictipes is shown in Fig. 1. C-banding showed centromeric heterochromatin in all autosome pairs and in the X chromosome (Fig. 2).

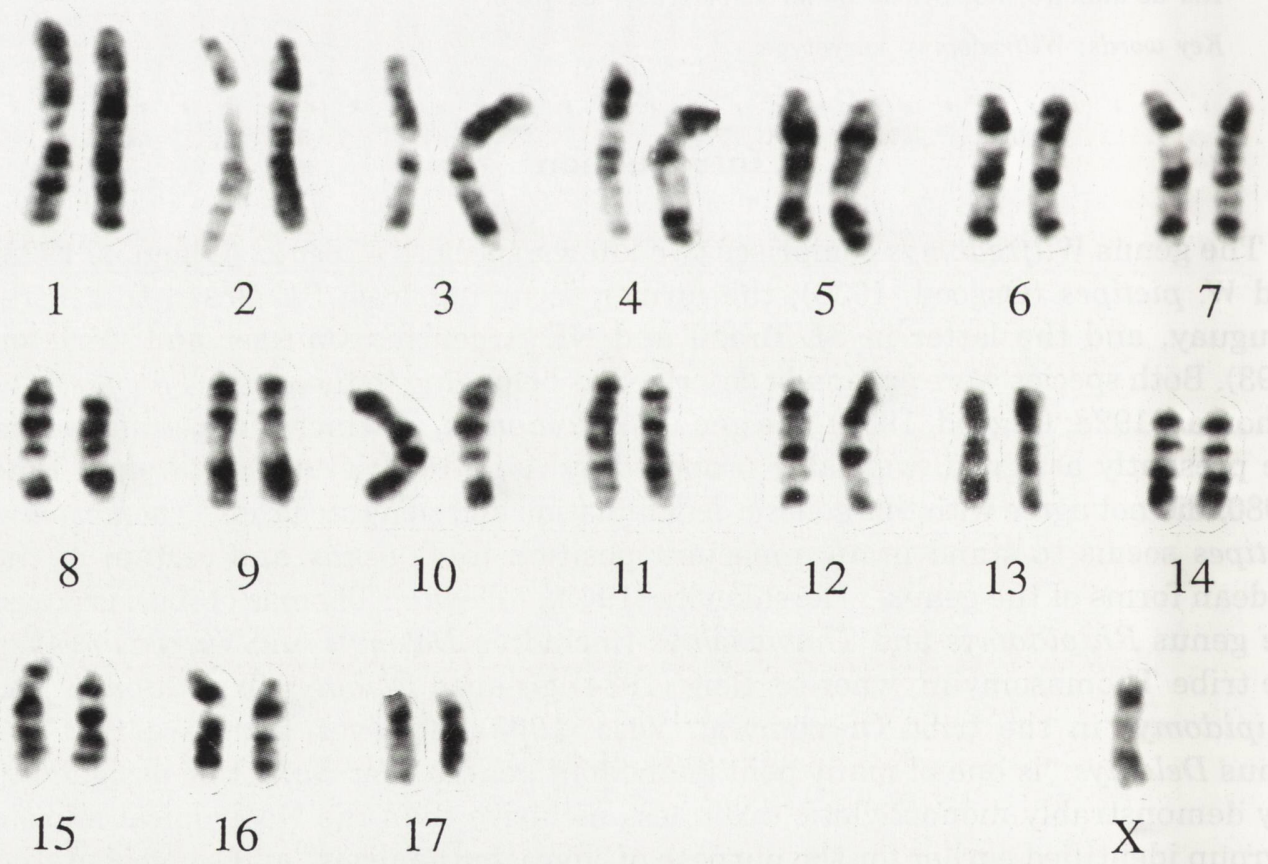

Fig. 1. G-band karyotype of Wilfredomys pictipes (male specimen, INT 4) from São Paulo State, Brazil ( $\mathrm{Y}$ chromosome is missing in this metaphase). 


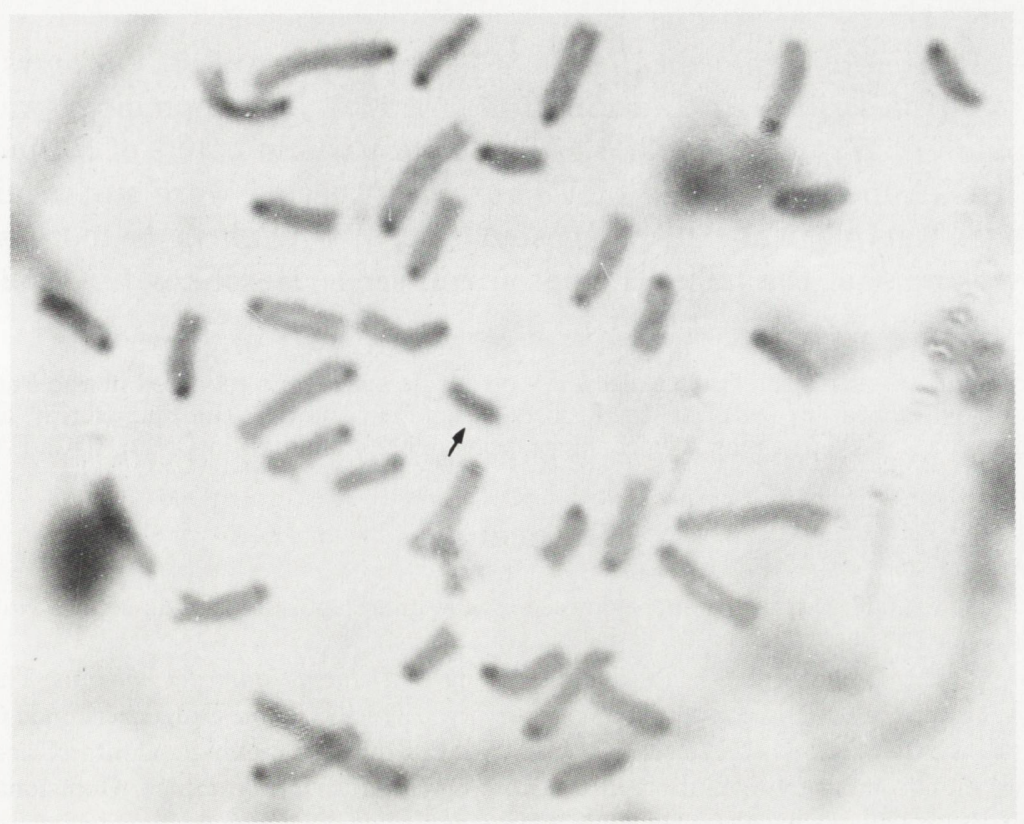

Fig. 2. C-banded metaphase of Wilfredomys pictipes. The Y chromosome is indicated by arrow.

\section{Discussion}

Morphological studies placed Wilfredomys either in the tribe Thomasomyini (Hershkovitz 1962) or Oryzomyini (Reig 1984) while Voss (1993) concluded that this genus did not belong to any of these tribes. Furthermore, Pine (1980) questioned the status of Wilfredomys and the relationship between W. pictipes and W. oenax.

Delomys, Rhipidomys and Wilfredomys are the only three Thomasomyini genera of Brazil for which karyotypic data are available. Delomys comprises three species, D. collinus with $2 \mathrm{n}=80 / \mathrm{FN}=86$ (Bonvicino and Geise 1995), and D. dorsalis and D. sublineatus with $2 \mathrm{n}=80 / \mathrm{FN}=80$ and $2 \mathrm{n}=74 / \mathrm{FN}=90$ respectively (Zanchin et al. 1992a). Rhipidomys comprises 22 species (Tribe 1996). In this genus, 20 species are characterized by a constant diploid number $(2 \mathrm{n}=44)$ but with a variable fundamental number, from 48 in R. latimanus (Gardner and Patton 1976) to 74 in $R$. mastacalis (Zanchin et al. 1992b). The other two species, R. nitela and $R$. cf. nitela showed $2 \mathrm{n}=48$ and $2 \mathrm{n}=50$ respectively (Tribe 1996). Wilfredomys comprises two species, karyotypically unknown to the present.

W. pictipes, herewith studied, showed $2 \mathrm{n}=36 / \mathrm{FN}=34$. This species was karyotypically different from Delomys species and from species of the tribe Oryzomyini sensu Voss (1993) in showing a lower diploid and fundamental number which is considered to be a derived trait among sigmodontine rodents (Reig 1984). The karyotype herewith described shared at least one homology with the G-band 
karyotype of Rhipidomys mastacalis $(2 \mathrm{n}=44 / \mathrm{FN}=74)$ and Rhipidomys $\mathrm{sp} .(2 \mathrm{n}=$ $44 / \mathrm{FN}=50$ ) described by Zanchin et al. (1992b). This homology was evident between pair 1 of $W$. pictipes, pair 1 of $R$. mastacalis and pair 2 of Rhipidomys sp. Conversely, G-band karyotypes of Tomasomys species were not available for comparisons. Karyological data suggested that Wilfredomys is more similar to Rhipidomys and that the tribe Thomasomyini sensu Hershkovitz (1962) is not a karyotypically homogeneous taxon.

Acknowledgements: We are grateful to Emerson Vieira from specimens collected in São Paulo State, to R. Cerqueira from laboratory facilities, to H. N. Seuánez for reviewing the manuscript, and to Sônia Maria Rodrigues da Costa for helping us with illustrations. Work supported by CNPq, INCa-FAF (Brazil).

\section{References}

Ávila-Pires F. D. de 1960. Um novo gênero de roedor Sul-Americano. Boletim do Museu Nacional, nova série, Zoologia 220: 1-6.

Bonvicino C. R. and Geise L. 1995. Taxonomic status of Delomys dorsalis collinus Thomas, 1917 (Rodentia, Cricetidae) and description of a new karyotype. Zeitschrift für Saügertierkunde 60: 124-127.

Gardner A. L. and Patton J. L. 1976. Karyotypic variation in Oryzomyine rodents (Cricetidae) with comments on chromosomal evolution in the neotropical cricetinae complex. Occasional Papers of Louisiana State University, Museum Zoology 49: 1-48.

Hershkovitz P. 1962. Evolution of Neotropical cricetine rodents (Muridae) with special reference to the phyllotine group. Fieldiana Zoology 46: 1-524.

Musser G. G. and Carleton M. P. 1993. Family Muridae. [In: Mammals species of the world. A taxonomic and geographic reference. D. E. Wilson and D. M. Reeder, eds]. Smithsonian Institution Press, Washington: 501-705.

Osgood W. H. 1933. Two new rodents from Argentina. Zoological Series, Field Museum of Natural History 20: 11-14.

Pine P. H. 1980. Notes on rodents of the genera Wiedomys and Thomasomys (including Wilfredomys). Mammalia 44: 195-202.

Reig O. 1984. Distribuição geográfica e história evolutiva dos roedores Muroideos Sulamericanos (Cricetidae: Sigmodontinae) (Geographic distribution and evolutionary history of South American muroids, Cricetidae: Sigmodontinae). Brazilian Journal of Genetics 7: 333-365.

Seabright M. 1971. A rapid banding technique for human chromosomes. Lancet 2: 971-972.

Sumner A. T. 1972. A simple technique for demonstrating centromeric heterochromatin. Experimental Cell Research 75: 304-306.

Thomas O. 1906. Notes on South American Rodents. Annals and Magazine of Natural History 7: 442-448.

Thomas O. 1928. A new Thomasomys from Rio Grande do Sul. Annals and Magazine of Natural History 10: 154-155.

Tribe C. J. 1996. The Neotropical rodents genus Rhipidomys (Cricetidae: Sigmodontinae) - a taxonomic revision. Unpublished Ph D thesis, University College London, London: 1-316.

Voss R. S. 1993. A revision of the Brazilian muroid rodent genus Delomys with remarks on "Thomasomyine" characters. American Museum of Novitates 3073: 1-44.

Zanchin N. I. T., Sbalqueiro I. J., Langguth A., Bossle R. C., Castro E. C., Oliveira L. F. B. and Mattevi M. S. 1992a. Karyotype and species diversity of the genus Delomys (Rodentia, Cricetidae) in Brazil. Acta Theriologica 37: 163-169.

Zanchin N., Langguth A. and Mattevi M. S. 1992b. Karyotypes of Brazilian species of Rhipidomys (Rodentia, Cricetidae). Journal of Mammalogy 73: 120-122. 